\title{
SOME CAUSES AND EFFECTS OF VARIATION IN THE RANGE OF TEMPERATURE.
}

By J. R. Sutron, Sc.D., F.R.S.S.Af., Hon. Memb. R.Met.S., and Elizabeth M. Sutton, F.R.Met.S.

(Read October 18, 1911.)

The present joint paper contains the results of a discussion of some of the more salient meteorological aspects of a variation in the range of air temperature. The investigation was instituted with the primary object of determining what variation, if any, of the diurnal curve of barometric pressure might accompany a greater or less range of temperature as night followed day; but other points had necessarily to be considered so that we might be able to assign as nearly as possible the position of the range curve in the sequence of meteorological cause and effect. We have, however, adhered to our original intention of making the range of temperature the basis of the argument.

The meteorological elements taken into account here are the monthly means of :-

1. The diurnal range of air temperature ;

2. The maximum temperature of the air ;

3. The minimum temperature of the air ;

4. The hourly mean temperature of the day;

5. The range of dew-point temperature from VIII. to XIV. ;

6 . The hourly mean dew-point temperature ;

7. The range of relative humidity from VIII. to XIV.;

8. The hourly mean relative humidity ;

9. The range of barometric pressure from VIII. to XIV.;

10. The hourly mean pressure;

11. The mean percentage of sunshine;

12. The mean percentage of cloud derived mainly from six observations a day ;

13. The mean rainfall ;

14. The total rainfall in the period studied. 
For each given month the month's mean values of each of these elements are arranged according to the magnitude of the range of temperature in any year 1897 to 1910, some months of 1911 having been included. The method of arrangement will be followed in Table 1, showing the results for one month, i.e., July, of which it is perhaps only necessary to say that the minus sign in the dew-point column indicates that the vapour pressure is less at VIII. o'clock than it is at XIV.; the plus sign when it occurs-in other months - that the vapour pressure is greater at XIV.

Table 2 gives for the year corresponding information to that which Table 1 gives for the month; the "A" line, of the year, containing for each column the averages of the "A " lines of each month; and so on for the "B," "C," "D," ... lines. The numbers in each column of Table 2 have, however, first of all been smoothed in threes by Bloxam's method.

Table 2 would seem to be of peculiar interest. With one exception all the elements in question respond to the rise and fall of the range of temperature curve. The following increase more or less regularly as the mean monthly range of temperature increases :-

2. The maximum temperature;

4. The mean temperature;

9. The range of pressure;

11. The duration of sunshine.

The following decrease more or less regularly as the range of temperature increases :-

3. The minimum temperature;

5. The range of the dew-point;

6. The mean dew-point;

7. The range of relative humidity;

8. The mean humidity;

12. The cloudiness of the sky;

13. The mean rainfall;

14. The number of rainy days in a month.

The one exception is the mean pressure of the month, which commences by falling, but concludes by rising as the range of temperature increases in magnitude. Whether this anomalous behaviour of the 
monthly value of mean pressure arises physically or fortuitously is not yet clear.

The general tendency of some of the results given in Table 2 is perhaps what would have been expected. Thus, e.g., we should expect that the greater cloudiness of the sky, the heavier rainfall, and the greater number of rainy days in any given month would go with a diminished percentage of sunshine. It is not so obvious, however, that these should also go with a uniform decrease of both maximum and mean temperature and an increase of both minimum temperature and range of temperature, especially when it is remembered that some of the hottest Kimberley summer days are to a greater or less extent characterised by clouded skies. Nor does it necessarily follow, as a mere piece of intellectual reasoning, that the range of dew-point temperature, or the range of relative humidity, should increase as the range of temperature decreases. In any case, whether the results are, or are not, much as might be expected, the actual measures are of interest. In particular, the mutual relationship of sunshine and cloud is worth attention. It will be seen that the sum of the percentages of sunshine and of cloud is not a constant quantity, but that it becomes greater as the range of temperature becomes less, rising from a total of 106 per cent. when the range of temperature is $32^{\circ} \cdot 6$ to a total of 114 per cent. when the range of temperature is $24^{\circ} \cdot 3$.

The minimum temperature does not rise at the same rate as the maximum temperature falls in the interval between the average month's greatest range of temperature to its least. Thus it comes about that the average month of least range of temperature is also the average month of least mean temperature. This is important. Professor Haughton's lectures have been quoted as teaching that the mildness of the climate of the West of Ireland is due to the abundant rainfall. It has been suggested that this mildness of temperature is a direct consequence of the heat disengaged in the process of condensation from aqueous vapour to rain. The suggestion does not hold water. The Kimberley results show that although the nights are a little warmer in the wet months the days are colder by a greater number of degrees. That is to say, whatever the "blanketing" action of the clouds may be, or whatever the quantity of heat disengaged in the process of condensation, the radiation that is checked by, and the latent heat that is received from the clouds, are together less than the direct solar heat that is shut off by the clouds from the earth's surface.

During the winter months the diurnal curve of dew-point temperature is quite unlike what it is in the summer. In the winter half-year, April to September, the vapour tension is higher at XIV. than it is at VIII., whereas for the rest of the year the case is the other way about. A sepa- 
ration of the winter and summer parts of column (5) of Table 2 gives us the following result :-

\section{Range of Monthly Dew-point Temperature compared with Monthly Range of Temperature.}

\begin{tabular}{|c|c|c|}
\hline$\cdot$ & Winter. & Summer. \\
\hline 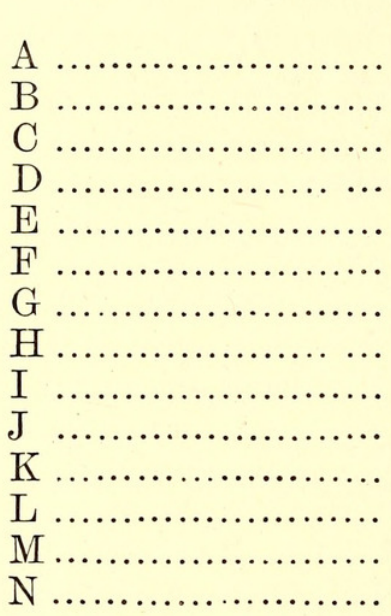 & $\begin{array}{r}\circ \\
-3 \cdot 4 \\
3 \cdot 3 \\
3 \cdot 1 \\
3 \cdot 1 \\
2 \cdot 8 \\
2 \cdot 8 \\
2 \cdot 6 \\
2 \cdot 6 \\
2 \cdot 5 \\
2 \cdot 5 \\
2 \cdot 2 \\
1 \cdot 7 \\
1 \cdot 5 \\
1 \cdot 6\end{array}$ & $\begin{array}{r}\stackrel{0}{ } \\
+1 \cdot 9 \\
2 \cdot 1 \\
2 \cdot 2 \\
2 \cdot 3 \\
2 \cdot 7 \\
3 \cdot 0 \\
2 \cdot 8 \\
2 \cdot 8 \\
2 \cdot 7 \\
2 \cdot 8 \\
2 \cdot 7 \\
2 \cdot 5 \\
2 \cdot 4 \\
2 \cdot 2\end{array}$ \\
\hline
\end{tabular}

giving the curious result that in the winter half-year the diurnal variation in the total moisture content of the lower air diminishes as the air becomes damper, whereas in the summer half-year the corresponding variation is less both when the sky is very clear and when it is very cloudy-an intermediate state of things with regard to the sky (and of course with regard to the range of temperature) giving the greatest range of dew-point from VIII. to XIV. o'clock. Summer and winter taken together obliterate this purely summer effect. The relative humidity has no similar analogue.

The only other question discussed in this paper is the effect of a variation in the range of temperature upon the harmonic constants in the diurnal curves of temperature and barometric pressure.

For any given month arranged as in Table 1, the first five lines $\mathrm{A}-\mathrm{E}$, and the last five $\mathrm{J}-\mathrm{N}$, are taken, and the mean diurnal curves of temperature and barometric pressure of each for the given month for the years which happen to fall in these respective two sets are computed. Thus, for example, the mean diurnal curves of temperature and barometric pressure for July for the years 1898, 1902, 1901, 1897, and 1906 are computed for the greater range of temperature (which here averages $\left.32^{\circ} .5\right)$; and the same two elements for the same month for the years $1909,1910,1908,1900$, and 1899, are computed for the lesser range of temperature (which here averages $27^{\circ} \cdot 0$ ). 
The constants of the first three harmonic terms in the diurnal curves of barometric pressure (deduced as above) for the greater, and for the less, ranges of temperature are set forth in Tables 3 and 4 respectively. It appears from these Tables that a difference in the monthly mean range of temperature makes no material difference in the phase times of either the 24-hour wave $\left(V_{I}\right)$, the 12 -hour wave $\left(V_{2}\right)$, or the 8 -hour wave $\left(V_{3}\right)$. The amplitudes $\left(u_{\mathrm{I}}, u_{2}, u_{3}\right)$ are nevertheless more or less dependent upon the range of temperature, besides depending-the first and third in particular - upon the time of year.

The following are the ratios, $u \alpha / u \beta$, of the amplitudes pertaining to the greater range of temperature to those pertaining to the lesser range :-

\begin{tabular}{|c|c|c|c|c|}
\hline & $\frac{\mathrm{M}-m}{a-\beta}$ & $\frac{u_{\mathrm{I}}}{\alpha / \beta}$ & $\frac{u_{2}}{\alpha / \beta}$ & $\frac{u_{3}}{\alpha / \beta}$ \\
\hline Jan. ...... & $6 \cdot 1$ & $1 \cdot 224$ & .996 & $1 \cdot 000$ \\
\hline Feb. ................ & $6 \cdot 1$ & $1 \cdot 273$ & $1 \cdot 142$ & 1.909 \\
\hline Mar. ................ & $5 \cdot 4$ & $1 \cdot 132$ & 1.055 & .923 \\
\hline April ............... & 6.5 & 1.075 & .967 & .976 \\
\hline May ................ & $7 \cdot 5$ & $1 \cdot 263$ & .988 & $1 \cdot 315$ \\
\hline June ............... & $3 \cdot 7$ & $1 \cdot 177$ & .958 & $1 \cdot 074$ \\
\hline July ............... & $5 \cdot 5$ & $1 \cdot 135$ & $1 \cdot 041$ & $1 \cdot 071$ \\
\hline Aug. ................ & $3 \cdot 1$ & $1 \cdot 153$ & .983 & $1 \cdot 196$ \\
\hline Sept................. & $5 \cdot 5$ & $1 \cdot 189$ & $1 \cdot 024$ & $0 \cdot 794$ \\
\hline Oct. .... & $4 \cdot 4$ & $1 \cdot 074$ & $1 \cdot 047$ & $10 \cdot 000$ \\
\hline Nov. ................ & $3 \cdot 9$ & $1 \cdot 051$ & $1 \cdot 063$ & $1 \cdot 611$ \\
\hline Dec. ............... & $3 \cdot 1$ & $1 \cdot 022$ & $\cdot 941$ & $1 \cdot 471$ \\
\hline Year............... & $5 \cdot 1$ & $1 \cdot 139$ & $1 \cdot 015$ & $1 \cdot 162$ \\
\hline
\end{tabular}

Judging by Tables 3 and 4 the direct dependence of the second and third harmonic terms upon the range of temperature must be slight at the best. On account of its regularity the ratio $\alpha / \beta$ given above is much more satisfactory for the first harmonic term than it is for the other two. Averages for all the months in which $\alpha-\beta$ exceeds its mean value $\left(=5^{\circ} \cdot 1\right)$ or falls short of it are :-

\begin{tabular}{c|c|c|c}
\hline $\begin{array}{c}\text { No. of } \\
\text { Cases. }\end{array}$ & $\frac{\mathrm{M}-m}{a-\beta}$ & $\frac{u_{\mathrm{I}}}{\alpha / \beta}$ & $\frac{u_{2}}{\alpha / \beta}$ \\
\hline 7 & $\circ \cdot 2$ & $1 \cdot 184$ & 1.030 \\
5 & 3.8 & 1.095 & .998 \\
\hline
\end{tabular}


It appears from this that the greater the difference between the ranges of temperature for any month given in Tables 3 and 4 , then the greater the ratio of $a$ to $\beta$ on the whole for both of the first two harmonic terms. No great faith can be placed upon the result for the second harmonic term, though. At the same time the ratio is suggestive, and should it be confirmed by a longer series of observations, we should have to conclude that some portion of the second harmonic term of pressure is of local origin.

The phase times of the harmonic terms of temperature, given in Tables 5 and 6 , are also practically unaffected whether the range of temperature be greater or less. The amplitudes, however, are rather more modified, than those of pressure. The following are the $\alpha / \beta$ ratios :-

\begin{tabular}{|c|c|c|c|c|}
\hline & $\frac{\mathrm{M}-m}{a-\beta}$ & $\frac{u_{\mathrm{I}}}{\alpha / \beta}$ & $\frac{u_{2}}{a / \beta}$ & $\frac{u_{3}}{\alpha / \beta}$ \\
\hline 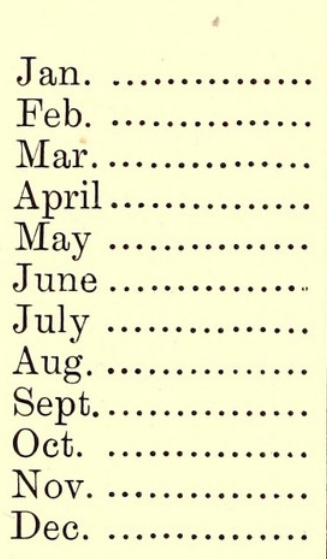 & $\begin{array}{l}6 \cdot 1 \\
6 \cdot 1 \\
5 \cdot 4 \\
6 \cdot 5 \\
7 \cdot 5 \\
3 \cdot 7 \\
5 \cdot 5 \\
3 \cdot 1 \\
5 \cdot 5 \\
4 \cdot 4 \\
3 \cdot 9 \\
3 \cdot 1\end{array}$ & $\begin{array}{l}1 \cdot 295 \\
1 \cdot 261 \\
1 \cdot 270 \\
1 \cdot 333 \\
1 \cdot 409 \\
1 \cdot 149 \\
1 \cdot 269 \\
1 \cdot 134 \\
1 \cdot 218 \\
1 \cdot 198 \\
1 \cdot 160 \\
1 \cdot 143\end{array}$ & $\begin{array}{r}1 \cdot 246 \\
1 \cdot 305 \\
1 \cdot 196 \\
1 \cdot 197 \\
1 \cdot 386 \\
1 \cdot 063 \\
1 \cdot 171 \\
1 \cdot 126 \\
1 \cdot 271 \\
1 \cdot 195 \\
\cdot 982 \\
1 \cdot 112\end{array}$ & $\begin{array}{l}1 \cdot 431 \\
1.322 \\
1.525 \\
1.961 \\
1.856 \\
1.611 \\
1.004 \\
1.257 \\
1 \cdot 400 \\
1.171 \\
1.597 \\
1.118\end{array}$ \\
\hline Year.............. & $5 \cdot 1$ & $1 \cdot 230$ & $1 \cdot 184$ & $1 \cdot 386$ \\
\hline
\end{tabular}

The ratios evidently depend fairly closely upon the value of $\alpha-\beta$, the first term more so than the other two do. A summary is :-

\begin{tabular}{c|c|c|c|c}
\hline $\begin{array}{c}\text { No. of } \\
\text { Cases. }\end{array}$ & $\frac{\mathrm{M}-m}{a-\beta}$ & $\frac{u_{\mathrm{I}}}{\alpha / \beta}$ & $\frac{u_{2}}{\alpha / \beta}$ & $\frac{u_{3}}{\alpha / \beta}$ \\
\cline { 2 - 4 } 7 & $\stackrel{0}{a / 2}$ & 1.294 & 1.253 & 1.500 \\
5 & 3.8 & 1.157 & 1.096 & 1.351 \\
\hline
\end{tabular}


That is to say, the ratios of the amplitudes are greater when $\alpha-\beta$ is greater.

The amplitudes $u_{\mathrm{I}}$, in Tables 5 and 6 , may be approximately represented by the formula-

$$
u_{\mathrm{r}}=\cdot 42(\mathrm{M}-m) .
$$

From some points of view the harmonic constants look better when computed for the "temperature variability," i.e., for the curve of change of temperature from hour to hour, than they do when they are computed for the hourly temperatures. The harmonic constants in the diurnal curves of temperature variability, or, if we prefer to call it so, in the $\Delta \theta / \Delta t$ curve-where $\theta$ is the temperature and $t$ the time counted from midnight-are given in Tables 7 and 8 . The angles $\mathrm{V}_{\mathrm{I}}, \mathrm{V}_{2}, \mathrm{~V}_{3}$, in this case of course differ by $\pi / 2$ from those of Tables 5 and 6 . The ratios of the amplitudes of temperature variability to those of temperature, for both greater and lesser ranges of temperature, are approximately-

$$
u_{\mathrm{r}}=3 \cdot 8 ; u_{2}=1 \cdot 9 ; u_{3}=1 \cdot 3 .
$$

The respective ratios of the amplitudes of temperature variability for the greater ranges of temperature $(\boldsymbol{\alpha})$ to the amplitudes for the lesser ranges $(\beta)$ are the same as those of temperature.

One advantage of working out the harmonic constants for the variability is that they bring into strong relief the fact that the phase times of the three principal waves, given in Tables 7 and 8 , group themselves closely about the phase time of the 12 -hour wave of pressure. In fact, all three of the variability component waves come to a maximum within about an hour or less of the time of a maximum of the pressure wave in question. This near coincidence of phase times in the first place, next the tendency which the phase times of the first and second harmonic components of temperature variability as well as the second component of barometric pressure show to come earlier in the day during the spring and early summer months; thirdly, the greater magnitude of the amplitude of the variability curve as well as of the second harmonic component of pressure at the same period; these go to support the idea that the 12-hour pressure wave arises initially as the result of the variation of temperature from instant to instant, and not as a result of temperature alone. Obviously the mere expansion of the air upwards could have no effect upon the pressure beneath, excepting by virtue of the reaction downwards, and this last must be greatest when the upward acceleration of the air is a maximum, i.e., when $d \theta / d t$ is a maximum.*

* See a remarkable paper by Halm published in the Journal of the Scottish Meteorological Society, Third Series, No. XXII., 1906. Also Sutton, “The Diurnal Variation of Barometric Pressure," Report S.A.A.A.S., 1906. Hann has yet another able paper, "Ueber die Zerlegung des komplexen taeglichen Ganges der Temperatur und des Luftdruckes in eine ganz- und eine halbtaegige Welle," in Met. Zeit., July, 1911. 
Tables 9 and 10 give the hourly mean barometric pressures at $32^{\circ} \mathrm{F}$. They are obtained from the records of the photobarograph, and have been reduced to agree with the control readings of the Observatory Standard Barometer. Table 9 contains the mean results for the greater ranges of temperature $(a)$, and Table 10 those for the lesser ranges $(\beta)$.

Tables 11, 12, give the hourly mean temperatures for the greater $(\alpha)$ and lesser $(\beta)$ ranges of temperature respectively. 
Causes and Effects of Variation in the Range of Temperature.

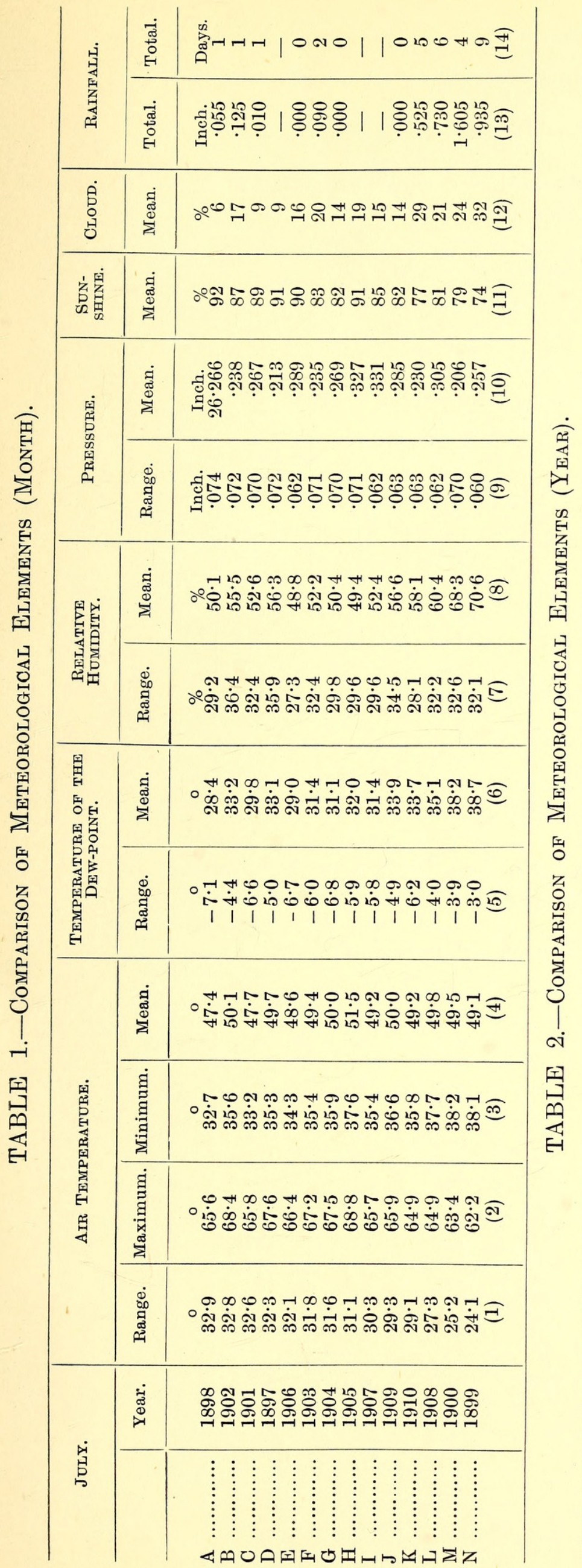

\begin{tabular}{|c|c|}
\hline 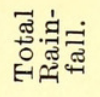 & 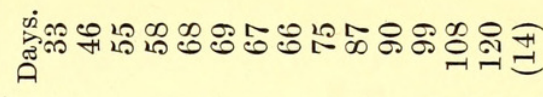 \\
\hline 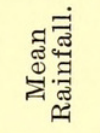 & 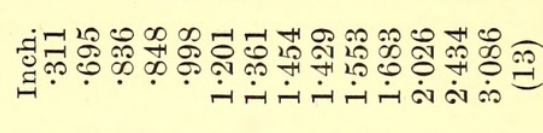 \\
\hline 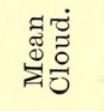 & 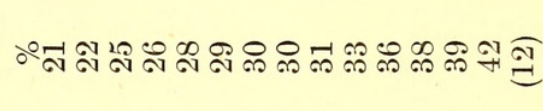 \\
\hline 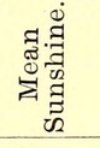 & 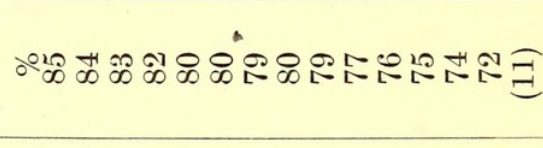 \\
\hline 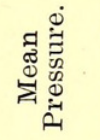 & 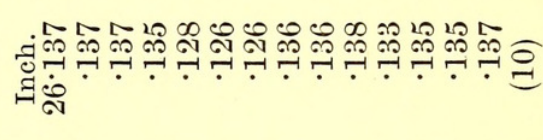 \\
\hline
\end{tabular}

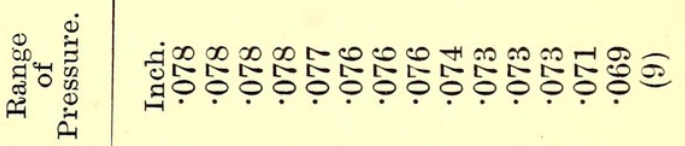

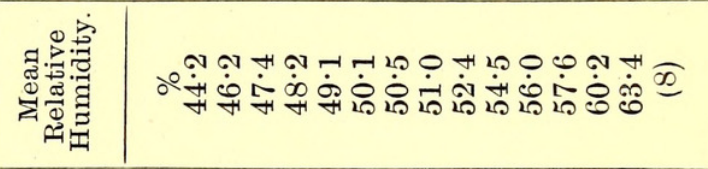

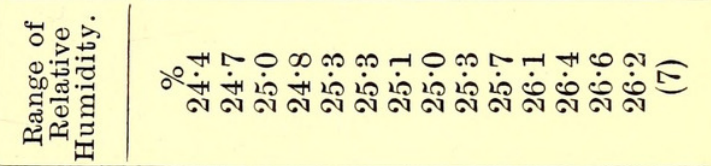

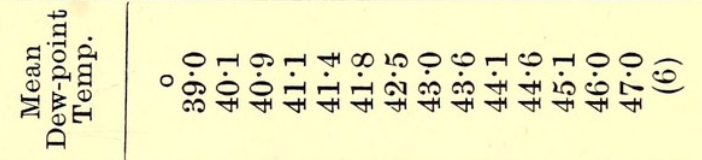

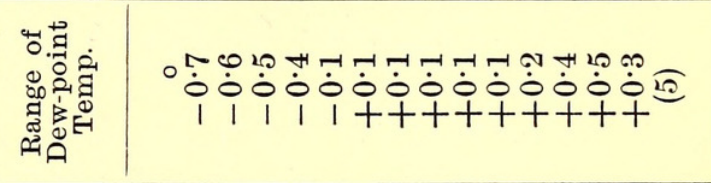

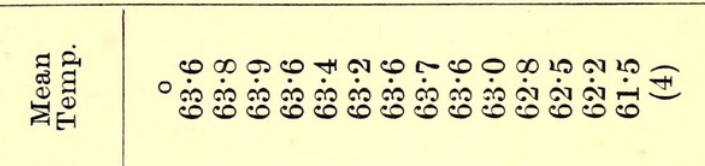

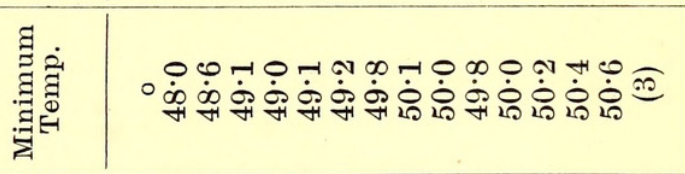

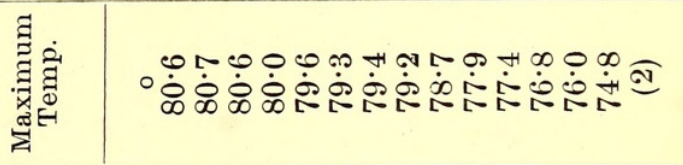

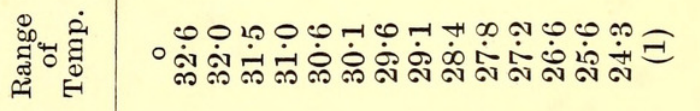

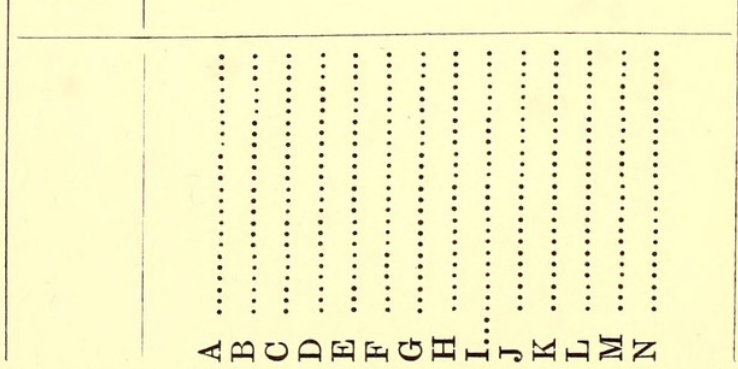


TABLE 3.

Harmonic Constants in the Diurnal Curves of Barometric Pressure.

a. For Greater Ranges of Temperature.

\begin{tabular}{|c|c|c|c|c|c|c|c|}
\hline & $\begin{array}{c}\text { Range of } \\
\text { Temperature }\end{array}$ & $u_{\mathrm{I}}$ & $u_{2}$ & $u_{3}$. & $\mathrm{V}_{\mathrm{I}}$ & $\mathrm{V}_{2}$ & $\mathrm{~V}_{3}$. \\
\hline $\operatorname{Jan} . . . . . . . . . . .$. & $\stackrel{\circ}{30} \cdot 2$ & $\begin{array}{l}\text { inch } \\
.0383\end{array}$ & $\begin{array}{l}\text { inch } \\
.0277\end{array}$ & inch & 360 & 15 & $\stackrel{\circ}{107}$ \\
\hline 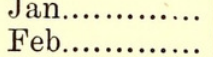 & $\begin{array}{l}30 \cdot 2 \\
30 \cdot 2\end{array}$ & $\begin{array}{l}.0383 \\
.0364\end{array}$ & $\begin{array}{l}.0277 \\
.0265\end{array}$ & $\begin{array}{l}\cdot 0051 \\
.0091\end{array}$ & $\begin{array}{l}360 \\
359\end{array}$ & 153 & 187 \\
\hline Mar. .............. & $28 \cdot 6$ & $\cdot 0295$ & $\cdot 0267$ & $\cdot 0012$ & $\begin{array}{l}009 \\
357\end{array}$ & $\begin{array}{l}101 \\
155\end{array}$ & 345 \\
\hline April ........... & $29 \cdot 5$ & $\cdot 0228$ & $\cdot 0260$ & $\cdot 0040$ & 350 & 159 & 10 \\
\hline May............ & $31 \cdot 1$ & $\cdot 0235$ & $\cdot 0255$ & $\cdot 0071$ & 353 & 157 & 355 \\
\hline June ......... & 30.5 & $\cdot 0234$ & $\cdot 0251$ & $\cdot 0073$ & 347 & 156 & 353 \\
\hline July $\quad \ldots . . . . .$. & $32 \cdot 5$ & $\cdot 0269$ & $\cdot 0254$ & $\cdot 0075$ & 351 & 154 & 356 \\
\hline Aug. ........... & $34 \cdot 1$ & $\cdot 0301$ & $\cdot 0283$ & $\cdot 0061$ & 350 & 157 & 2 \\
\hline Sept. ........... & $34 \cdot 8$ & $\cdot 0327$ & $\cdot 0306$ & $\cdot 0027$ & 2 & 165 & 21 \\
\hline Oct............. & $32 \cdot 7$ & $\cdot 0350$ & $\cdot 0290$ & $\cdot 0010$ & 5 & 168 & 91 \\
\hline Nov. $\ldots \ldots \ldots \ldots$ & $33 \cdot 2$ & $\cdot 0373$ & $\cdot 0271$ & $\cdot 0029$ & 3 & 164 & 173 \\
\hline Dec. .......... & $30 \cdot 3$ & $\cdot 0370$ & $\cdot 0240$ & $\cdot 0050$ & 1 & 161 & 183 \\
\hline Year ......... & $31 \cdot 5$ & $\cdot 0311$ & $\cdot 0268$ & $\cdot 0043$ & 356 & 158 & - \\
\hline
\end{tabular}

TABLE 4.

Harmonic Constants in the Diurnal Curves of Barometric Pressure.

$\beta$. For Lesser Ranges of Temperature.

\begin{tabular}{|c|c|c|c|c|c|c|c|c|}
\hline & & $\begin{array}{c}\text { Range of } \\
\text { Temperature. }\end{array}$ & $u_{1}$ & $u_{2}$ & $u_{3}$. & $\mathrm{V}_{\mathrm{I}}$. & $\mathrm{V}_{2}$ & $\mathrm{~V}_{3}$. \\
\hline Jan. & $\ldots$ & $\begin{array}{c}\circ \\
24 \cdot 1\end{array}$ & $\begin{array}{l}\text { inch } \\
.0313\end{array}$ & $\begin{array}{l}\text { inch } \\
.0278\end{array}$ & $\begin{array}{l}\text { inch } \\
.0051\end{array}$ & $\begin{array}{c}\circ \\
359\end{array}$ & $\stackrel{\circ}{157}$ & $\stackrel{\circ}{178}$ \\
\hline Feb. & ......... & $24 \cdot 1$ & $\cdot 0286$ & $\cdot 0232$ & $\cdot 0011$ & 351 & 154 & 194 \\
\hline Mar. & .......... & $23 \cdot 2$ & $\cdot 0260$ & $\cdot 0253$ & $\cdot 0013$ & 357 & 152 & 16 \\
\hline April & .......... & $23 \cdot 0$ & $\cdot 0212$ & $\cdot 0269$ & $\cdot 0041$ & 350 & 154 & 7 \\
\hline May & ........... & $23 \cdot 6$ & $\cdot 0186$ & $\cdot 0258$ & $\cdot 0054$ & 356 & 160 & 356 \\
\hline June & ......... & $26 \cdot 8$ & $\cdot 0199$ & $\cdot 0262$ & $\cdot 0068$ & 348 & 160 & 346 \\
\hline July & ......... & $27 \cdot 0$ & $\cdot 0237$ & $\cdot 0244$ & $\cdot 0070$ & 351 & 154 & 357 \\
\hline Aug. & ......... & $31 \cdot 0$ & $\cdot 0261$ & $\cdot 0288$ & $\cdot 0051$ & 358 & 157 & 355 \\
\hline Sept. & .......... & $29 \cdot 3$ & $\cdot 0275$ & $\cdot 0299$ & $\cdot 0034$ & 3 & 166 & 12 \\
\hline Oct.... & ........... & $28 \cdot 3$ & $\cdot 0326$ & $\cdot 0277$ & $\cdot 0001$ & 4 & 166 & 95 \\
\hline Nov. & .......... & $29 \cdot 3$ & $\cdot 0355$ & $\cdot 0255$ & $\cdot 0018$ & 4 & 166 & 167 \\
\hline Dec. & .. ...... & $27 \cdot 2$ & $\cdot 0362$ & $\cdot 0255$ & $\cdot 0034$ & 2 & 157 & 183 \\
\hline Year & .......... & $26 \cdot 4$ & $\cdot 0273$ & $\cdot 0264$ & $\cdot 0037$ & 357 & 158 & - \\
\hline
\end{tabular}


Causes and Effects of Variation in the Range of Temperature. 351

TABLE 5 .

Harmonic Constants in the Diurnal Curves of Temperature.

a. For Greater Ranges of Temperature.

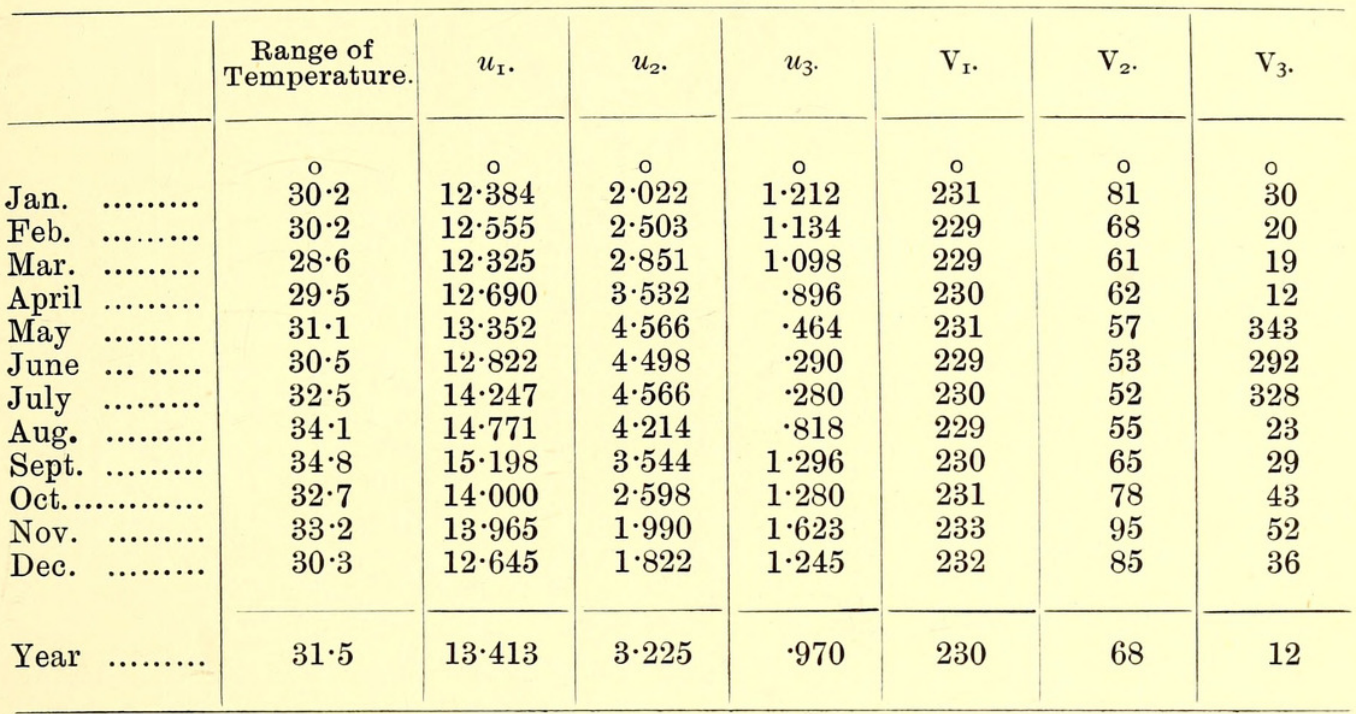

TABLE 6.

Harmonic Constants in the Diurnal Curves of Temperature.

$\beta$. For Lesser Ranges of Temperature.

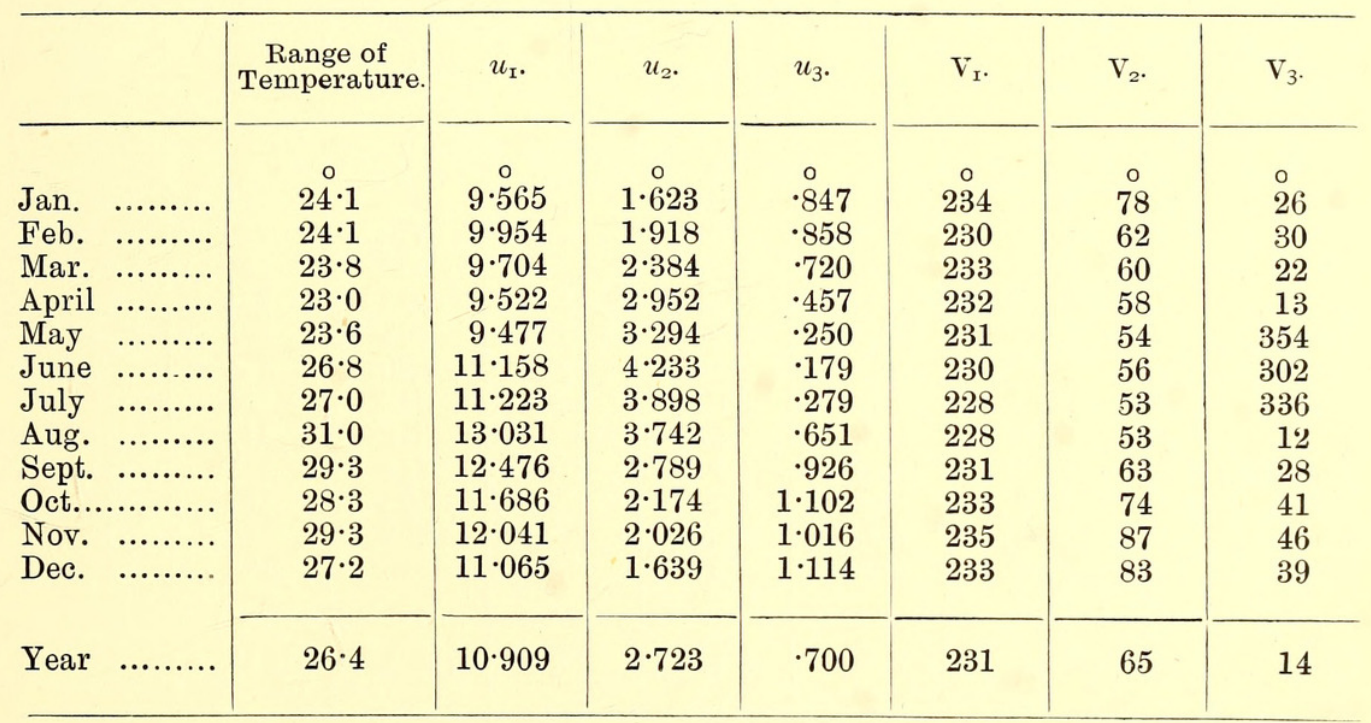




\section{TABLE 7.}

\section{Harmonic Constants in the Diurnal Curves of Temperature VARIABILITY.}

a. For Greater Ranges of Temperature.

\begin{tabular}{|c|c|c|c|c|c|c|c|}
\hline & $\begin{array}{c}\text { Range of } \\
\text { Temperature }\end{array}$ & $u_{\mathrm{I}}$. & $u_{2}$ & $u_{3}$ & $\mathrm{~V}_{\mathrm{I}}$ & $\mathrm{V}_{2}$ & $\mathrm{v}_{3}$. \\
\hline Jan. ......... & $\begin{array}{c}\circ \\
30 \cdot 2\end{array}$ & $\begin{array}{c}\circ \\
3 \cdot 233\end{array}$ & $1 \cdot \stackrel{\circ}{0} 046$ & $\begin{array}{c}\circ \\
.927\end{array}$ & $\begin{array}{c}\circ \\
321\end{array}$ & $\stackrel{\circ}{\circ}$ & $\stackrel{\circ}{120}$ \\
\hline Feb. $\quad \ldots \ldots \ldots$ & $30 \cdot 2$ & $3 \cdot 277$ & $1 \cdot 294$ & .864 & 319 & 158 & 109 \\
\hline Mar. .......... & $28 \cdot 6$ & $3 \cdot 218$ & $1 \cdot 444$ & $\cdot 840$ & 319 & 150 & 109 \\
\hline April ......... & $29 \cdot 5$ & $3 \cdot 313$ & $1 \cdot 828$ & $\cdot 685$ & 320 & 152 & 102 \\
\hline May ......... & $31 \cdot 1$ & $3 \cdot 486$ & $2 \cdot 310$ & $\cdot 357$ & 321 & 147 & 73 \\
\hline June ......... & $30 \cdot 5$ & $3 \cdot 348$ & $2 \cdot 356$ & $\cdot 222$ & 319 & 143 & 22 \\
\hline July ........ & $32 \cdot 5$ & $3 \cdot 719$ & $2 \cdot 364$ & $\cdot 218$ & 320 & 142 & 58 \\
\hline Aug. .......... & $34 \cdot 1$ & $3 \cdot 800$ & $2 \cdot 246$ & $\cdot 711$ & 319 & 144 & 113 \\
\hline Sept. $\ldots \ldots \ldots \ldots$ & $34 \cdot 8$ & $3 \cdot 968$ & $1 \cdot 836$ & •992 & 320 & 155 & 119 \\
\hline Oct............ & $32 \cdot 7$ & $3 \cdot 655$ & $1 \cdot 338$ & $\cdot 980$ & 321 & 168 & 133 \\
\hline Nov. . ......... & $33 \cdot 2$ & $3 \cdot 645$ & $1 \cdot 030$ & $1 \cdot 242$ & 323 & 185 & 141 \\
\hline Dec. $\quad \ldots . . . . .$. & $30 \cdot 3$ & $3 \cdot 308$ & $\cdot 950$ & $\cdot 946$ & 322 & 174 & 126 \\
\hline Year ......... & $31 \cdot 5$ & $3 \cdot 498$ & $1 \cdot 670$ & $\cdot 749$ & 320 & 158 & 102 \\
\hline
\end{tabular}

TABLE 8 .

Harmonic Constants in the Diurnal Curves of Temperature VARIABILITY.

$\beta$. For Lesser Ranges of Temperature.

\begin{tabular}{|c|c|c|c|c|c|c|c|}
\hline & $\begin{array}{c}\text { Range of } \\
\text { Temperature }\end{array}$ & $u_{\mathrm{I}}$ & $u_{2}$ & $u_{3}$ & $\mathrm{~V}_{\mathrm{I}}$ & $\mathrm{V}_{2}$ & $\mathrm{~V}_{3}$. \\
\hline Jan. & $\stackrel{\circ}{24 \cdot 1}$ & $\stackrel{\stackrel{\circ}{4}}{2} \cdot \frac{}{9}$ & $\stackrel{\circ}{845}$ & $\stackrel{\circ}{668}$ & $\begin{array}{c}\circ \\
324\end{array}$ & $\stackrel{\circ}{167}$ & $\stackrel{\circ}{117}$ \\
\hline Feb. & $24 \cdot 1$ & 2.599 & $\cdot 990$ & $\cdot 657$ & 320 & 152 & 120 \\
\hline Mar. $\quad . . . . . . . . . .$. & $23 \cdot 2$ & $2 \cdot 530$ & $1 \cdot 234$ & .552 & 323 & 150 & 112 \\
\hline April ........... & $23 \cdot 0$ & $2 \cdot 486$ & $1 \cdot 528$ & $\cdot 349$ & 322 & 147 & 103 \\
\hline May ......... & $23 \cdot 6$ & $2 \cdot 473$ & $1 \cdot 705$ & $\cdot 198$ & 321 & 145 & 84 \\
\hline June ......... & $26 \cdot 8$ & $2 \cdot 913$ & $2 \cdot 190$ & $\cdot 137$ & 320 & 146 & 32 \\
\hline July $\quad \ldots . . . . .$. & $27 \cdot 0$ & $2 \cdot 930$ & $2 \cdot 018$ & $\cdot 207$ & 318 & 143 & 65 \\
\hline Aug. .......... & $31 \cdot 0$ & $3 \cdot 402$ & 1.952 & $\cdot 498$ & 318 & 142 & 102 \\
\hline Sept. .......... & $29 \cdot 3$ & $3 \cdot 257$ & $1 \cdot 445$ & $\cdot 709$ & 321 & 153 & 118 \\
\hline Oct.............. & $28 \cdot 3$ & $3 \cdot 098$ & $1 \cdot 128$ & $\cdot 843$ & 323 & 164 & 131 \\
\hline Nov. .......... & $29 \cdot 3$ & $3 \cdot 144$ & $1 \cdot 049$ & $\cdot 778$ & 325 & 177 & 136 \\
\hline Dec. $\quad \ldots \ldots \ldots$ & $27 \cdot 2$ & $2 \cdot 926$ & $\cdot 848$ & $\cdot 853$ & 323 & 173 & 129 \\
\hline Year ........ & $26 \cdot 4$ & $2 \cdot 855$ & $1 \cdot 411$ & $\cdot 537$ & 321 & 155 & 104 \\
\hline
\end{tabular}


Causes and Effects of Variation in the Range of Temperature. 353

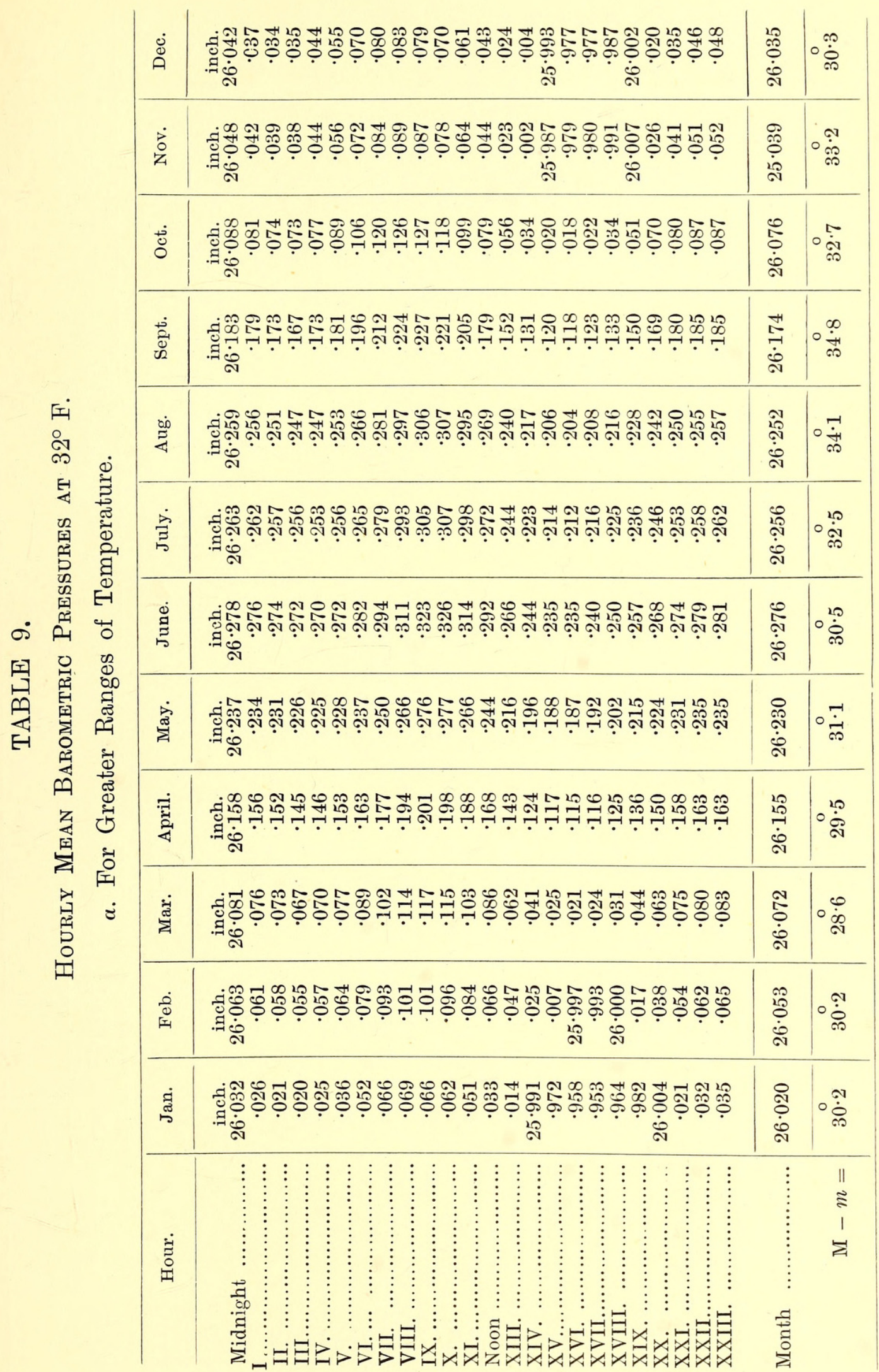




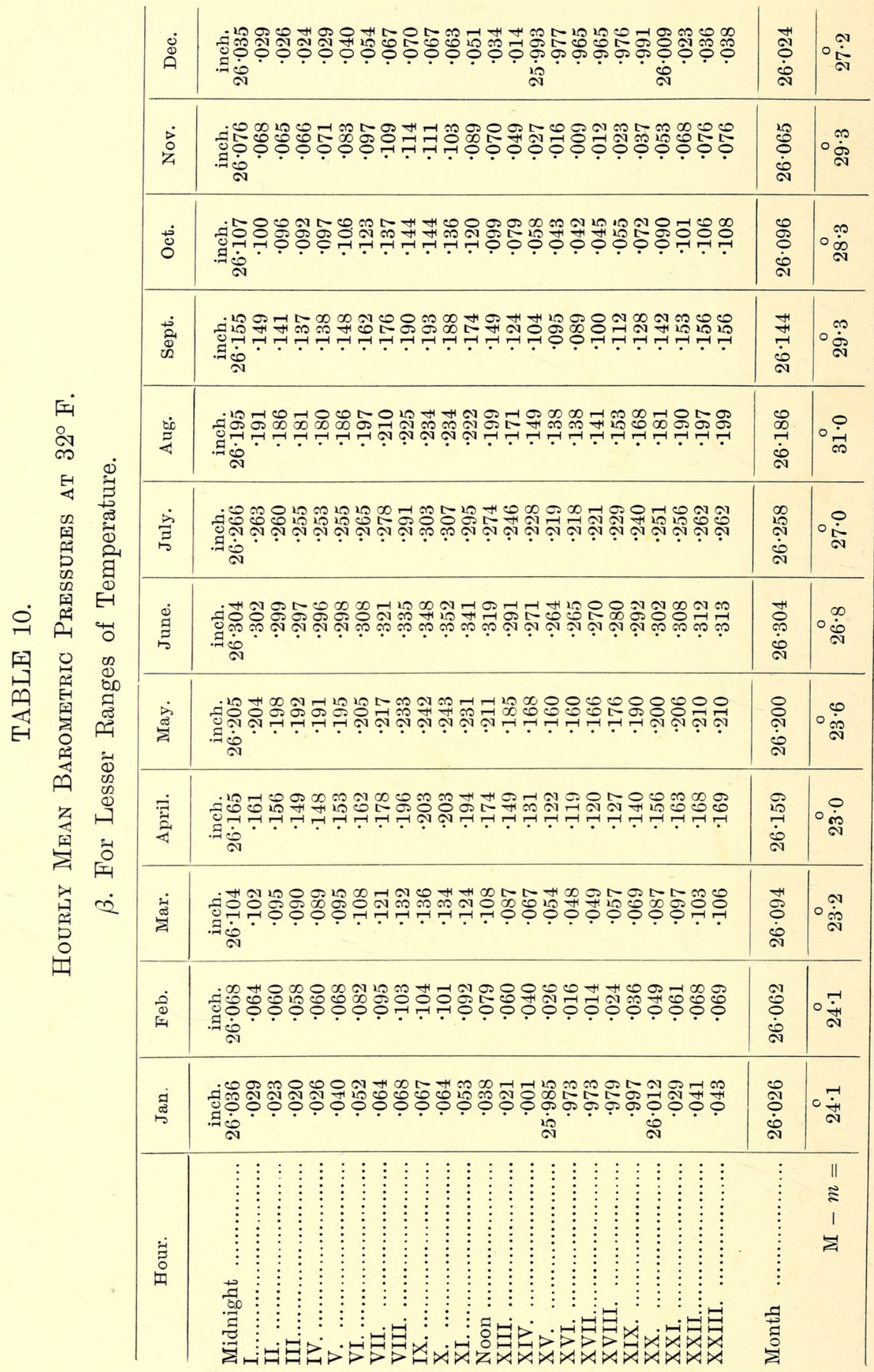


Causes and Effects of Variation in the Range of Temperature. 355

\begin{tabular}{|c|c|c|c|c|}
\hline \multirow{13}{*}{ 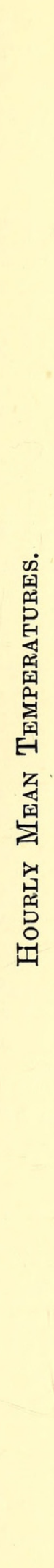 } & & $\stackrel{\varpi}{\Perp}$ & 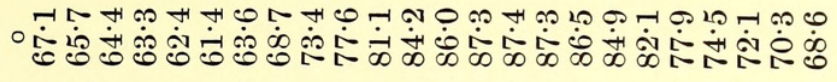 & $\stackrel{\circ}{\dot{L}}$ \\
\hline & . & ra & 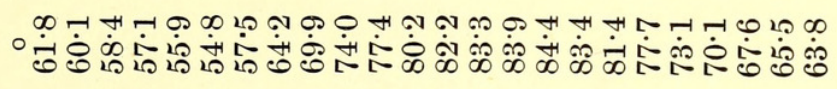 & $\stackrel{\leftrightarrow}{\circ}$ \\
\hline & & 0 & 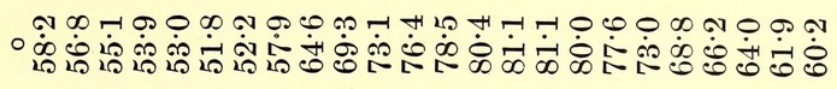 & iी \\
\hline & & 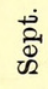 & 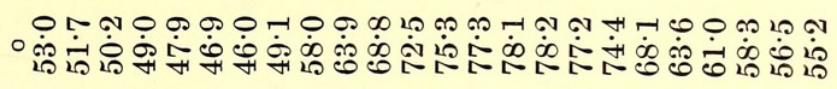 & $\stackrel{\leftarrow}{\vec{b}}$ \\
\hline & & $\stackrel{\infty}{4}$ & 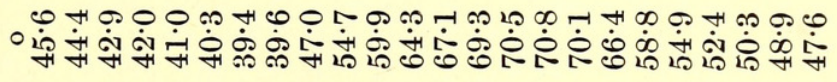 & 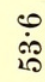 \\
\hline & $\stackrel{0}{\circlearrowright}$ & $\stackrel{\leftrightarrow}{\vec{\Xi}}$ & 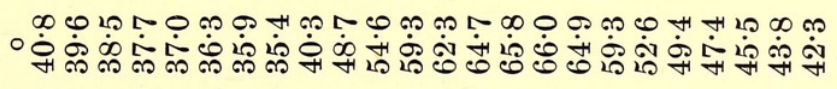 & $\stackrel{\Gamma}{\dot{\alpha}}$ \\
\hline & 苂 & $\underset{\Xi}{\Xi}$ & 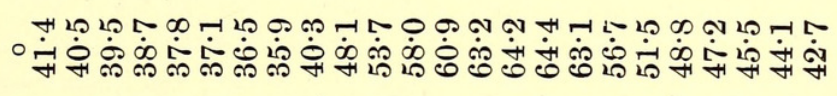 & 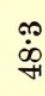 \\
\hline & $\overrightarrow{0}$ & 金 & 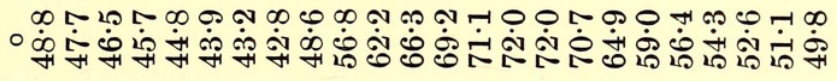 & $\begin{array}{ll}\infty \\
i{ }^{2}\end{array}$ \\
\hline & भी & 赔 & 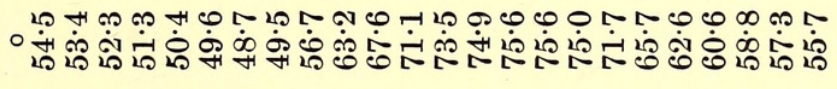 & $\stackrel{20}{\dot{6}}$ \\
\hline & 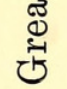 & ๘ึं & 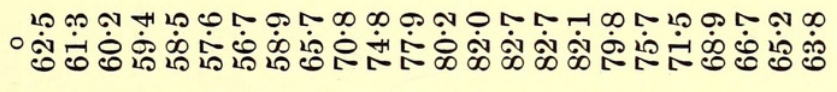 & $\ddot{8}$ \\
\hline & Ir & 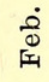 & 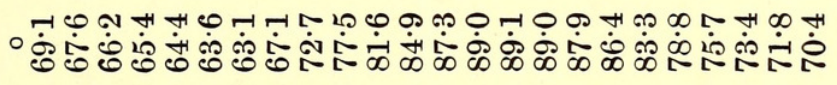 & $\overrightarrow{0}$ \\
\hline & & డ్శ & 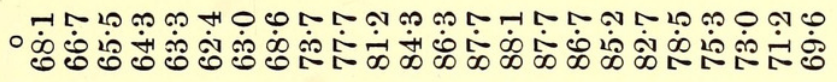 & i⿱ \\
\hline & & 䓂 & 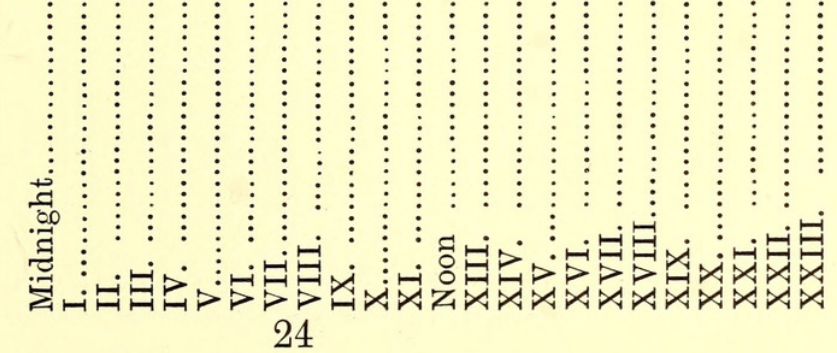 & 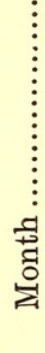 \\
\hline
\end{tabular}




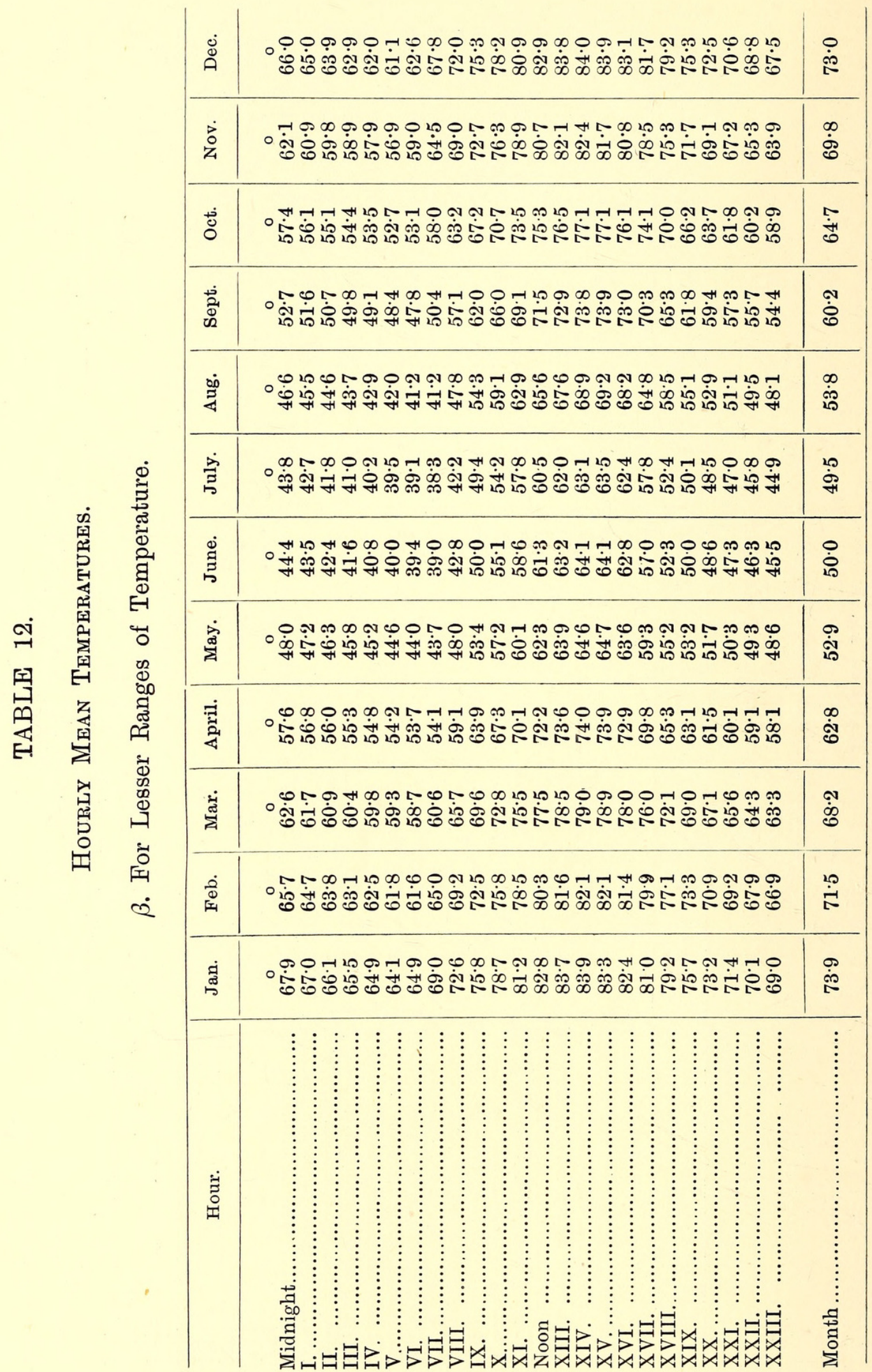




\section{$2 \mathrm{BHL}$ Biodiversity Heritage Library}

Sutton, J R and Sutton, Elizabeth M . 1910. "SOME CAUSES AND EFFECTS OF VARIATION IN THE RANGE OF TEMPERATURE." Transactions of the Royal Society of South Africa 2, 341-356. https://doi.org/10.1080/00359191009519393.

View This Item Online: https://www.biodiversitylibrary.org/item/181596

DOI: https://doi.org/10.1080/00359191009519393

Permalink: https://www.biodiversitylibrary.org/partpdf/175498

\section{Holding Institution}

Smithsonian Libraries

\section{Sponsored by}

Biodiversity Heritage Library

\section{Copyright \& Reuse}

Copyright Status: Not in copyright. The BHL knows of no copyright restrictions on this item.

This document was created from content at the Biodiversity Heritage Library, the world's largest open access digital library for biodiversity literature and archives. Visit BHL at https://www.biodiversitylibrary.org. 